\title{
MECHANICAL HARVESTING OF COFFEE IN HIGH SLOPE ${ }^{1}$
}

\author{
FELIPE SANTINATO $^{2 *}$, ROUVERSON PEREIRA DA SILVA ${ }^{2}$, VANTUIR DE ALBUQUERQUE SILVA ${ }^{2}$, CARLOS \\ DIEGO DA SILVA ${ }^{3}$, TIAGO DE OLIVEIRA TAVARES ${ }^{2}$
}

\begin{abstract}
Brazilian coffee farming is carried out both on flat and steep lands. In flat areas, mechanized operations are intensive; however, in steep slope areas, certain mechanized operations cannot be performed, such as harvesting. Based on this, the industry has developed machinery to harvest coffee in areas with up to $30 \%$ slope. However, harvesters have their efficiency and operational performance influenced by land slope. Thus, this study aimed to evaluate the operational performance and harvesting efficiency of a steep-slope harvester under different situations, using different speed settings. The experiment was carried out in the county of Santo Antônio do Amparo, state of Minas Gerais, Brazil, using five coffee stands with 10, 15, 20, 25 and $30 \%$ slope. Evaluations were performed with a self-propelled harvester (Electron, TDI ${ }^{\circledR}$, Araguari, MG, Brazil) at three rotation speeds $(600,800$ and $1.000 \mathrm{rpm})$ and two ground speeds $\left(800\right.$ and $\left.1.000 \mathrm{~m} \mathrm{~h}^{-1}\right)$. The results showed the lower speed $\left(800 \mathrm{~m} \mathrm{~h}^{-1}\right)$ was suitable for $10 \%$ slope areas since the amount of fallen coffee berries. For areas of $20 \%$ slope, harvesting time was $21.6 \%$ longer than in flatter areas. Downtime varied from 10.66 to $29.18 \%$ total harvest due to a higher number of maneuvers.
\end{abstract}

Keywords: Modified harvesters. Steep-sloping relief. Mechanization.

\section{COLHEITA MECANIZADA DO CAFÉ EM ELEVADAS DECLIVIDADES}

RESUMO - A cafeicultura brasileira está presente em áreas planas e declivosas. Nas regiões planas a mecanização nas operações cafeeiras é intensa, do contrário, são as regiões declivosas, que não mecanizam algumas das operações, dentre elas a colheita. Para suplantar esta dificuldade a indústria vem desenvolvendo colhedoras capazes de colher em declividades de até 30\%. O desempenho operacional e a eficiência de colheita são influenciadas pela declividade. Diante disto objetivou-se no presente trabalho avaliar o desempenho operacional e a eficiência de colheita de uma colhedora confeccionada para colher em elevadas declividades, testando suas principais regulagens. O experimento foi conduzido no município de Santo Antônio do Amparo, região do Sul de Minas Gerais, em cinco talhões com declividade de 10, 15, 20, 25 e 30\%, utilizando uma colhedora Electron automotriz (TDI), testando três vibrações das hastes $(600,800$ e $1.000 \mathrm{rpm})$ e duas velocidades ( $800 \mathrm{e} 1.000 \mathrm{~m} \mathrm{~h}^{-1}$ ). Obteve-se que em na declividade de $10 \%$, deve-se utilizar velocidades reduzidas $\left(800 \mathrm{~m} \mathrm{~h}^{-1}\right)$ para minimizar a quantidade de café caído. Em declividades acima de $20 \%$ a colheita mecanizada demanda $21,6 \%$ a mais de tempo para ser procedida que em declividades menores. O tempo de parada na operação da colheita mecanizada corresponde a 10,66 a 29,18\% do tempo total de colheita, em função do maior número de manobras.

Palavras-chave: Colhedoras adaptadas. Relevo montanhoso. Mecanização.

\footnotetext{
*Corresponding Author

${ }^{1}$ Received for publication in 04/28/2015; accepted in 04/02/2016.

${ }^{2}$ Department of Rural Engineering, Universidade Estadual Paulista, Jaboticabal, SP, Brazil; fpsantinato@hotmail.com, rouverson@fcav.unesp.br, albuquerque.vantuir@yahoo.com.br, tiagoolitavares@hotmail.com.

${ }^{3}$ Department of Rural Engineering, Universidade Federal de Viçosa, Rio Paranaíba, MG, Brazil; carlosdiego_agro@hotmail.com.
} 


\section{INTRODUCTION}

One of the great challenges for coffee mechanized harvesting comprises its feasibility and improvement in steep slope lands. This type of research has been carried out in countries as Colombia, in which coffee plantations are predominantly on mountainous areas (CÁRDENAS et al., 2013; CÁRDENAS et al., 2015).

In the southern region of Minas Gerais, around $66.74 \%$ of the territorial areas are occupied with coffee fields $(290,126$ ha). These areas have slopes of up to $15 \%$, which is suitable for management and mechanical harvesting. The remnant area $(33.26 \%$ - $144,585.82 \mathrm{ha})$ is regarded as unsuitable for mechanization, being thus exclusively manually harvested (SILVA et al., 2009). In addition to this region, there are other coffee-producing regions in Brazil, for both arabica and conilon varieties, lying on hilly relieves such as Zona da Mata in the states of Minas Gerais and Espírito Santo, which comprises approximately 738,910 ha; however, a large part of this area is unable for mechanization (CONAB , 2014).

Once mechanized harvesting reduce farming costs in 50 to $60 \%$, its viability in unsuitable areas might reduce production expenses of farmers (LANNA; REIS, 2012; SANTINATO et al., 2015 b), increasing thus their profits.

Some harvesters such as those self-propelled are designed to overcome difficulties imposed by terrain undulation through a height-fit individualized system on either side of the harvester, leveling it according to terrain slope. Machinery harvesting in steep lands must have its operating performance and harvesting efficiency measured, since declivity may restrict performance at speeds above $1,000 \mathrm{~m} \mathrm{~h}^{-1}$, as currently applied in flat areas of Cerrado in Minas Gerais state (SANTINATO et al., 2014a). Besides that, the height difference between both sides of a harvester may increase the amount of fallen coffee berries, resulting in lower crop efficiency.

Another important point that ought to be studied in mechanical harvesting at high-slope areas concerns about time spent during operation. In this regard, it is common to come across large differences between theoretical and effective working time. Normally, times are underestimated reflecting in operational cost increases as well as dimensioning errors of machinery fleet to be used in operations. According to the available methodology for such calculations, in coffee farming, downtimes and maneuvers are responsible for $20 \%$ increase in time spent on mechanical harvesting operations (OLIVEIRA et al., 2007 b). This time is higher in high slope areas because of a greater number of stoppages during harvesting.

Therefore, given the above considerations, this study aimed at finding the most efficient machinery setting for coffee harvesting in a $10 \%$ slope area using a self-propelled harvester, besides measuring the demanded time for mechanized harvesting from slopes between 10 to $30 \%$.

\section{MATERIAL AND METHODS}

Two field studies were conducted at the Santa Felicidade farm, in the county of Santo Antonio do Amparo - MG, Brazil. The area is located at the geographical coordinates of $20^{\circ} 51^{\prime} 18^{\prime \prime}$ South latitude and $44^{\circ} 54^{\prime} 18^{\prime \prime}$ West Longitude, in the southern region of Minas Gerais state, with an average altitude of $1,050 \mathrm{~m}$ and Cwa type climate according to Köppen's classification (KOEPPEN, 1948).

The first experiment aimed at assessing different machine settings as rotation and ground speeds to reach a proper harvesting efficiency. We assessed harvesting in a typical coffee plantation of the southern Minas Gerais state. These fields are characterized as semi-dense spacing plantations on slopes above $10 \%$, aside from having high-sized plants and producing average yields (from 20.0 to 30.0 coffee bags ha ${ }^{-1}$ ) (MATIELLO et al.., 2010).

The second experiment focused on evaluations of harvesting duration at different land slopes by measuring times spent in maneuvers and stops, calculating thus the effective time of operation. In addition, we determined the operational field capacity (OFC) throughout mechanized coffee harvest at each slope.

In both experiments, we used a self-propelled harvester, Electron model, from TDI Máquinas Agrícolas ${ }^{\circledR}$, with 1366 operating hours. The equipment was manufactured in 2013 and its engine is rated at $67 \mathrm{hp}$ at $1,800 \mathrm{rpm}$ with a torque of $274 \mathrm{Nm}$. The main difference between this model and the conventional one is an independent height adjustment system, which is individualized for each harvester side. The tractor has wheel sets with hydraulic cylinder that elevates or lowers harvester height due to the soil leveling.

The areas assessed in both experiments were grown with coffee plants of 'Mundo Novo' cultivar. These plants are approximately $4.0 \mathrm{~m}$ high and spaced in $3.8 \mathrm{~m}$ between rows and $0.7 \mathrm{~m}$ between plants, reaching average yields of 23.55 coffee bags $\mathrm{ha}^{-1}$. The experimental areas showed differences only with respect to slope, wherein $10 \%$ slope was highlighted in the first experiment, and variable slopes in the second one.

In experiment one, treatments consisted of a 3 x 2 factorial scheme, testing three axial rotation speed and two ground speeds. The applied rotation speed were of $10,13.333$ and $16.666 \mathrm{~Hz}$, corresponding to 600,800 and $1,000 \mathrm{rpm}$, being considered weak, intermediate and strong (OLIVEIRA et al., 2007, SANTINATO et al., 2014 a). Yet the measured ground speeds were 800 
and $1,000 \mathrm{~m} \mathrm{~h}^{-1}$, which are commonly used in mechanical harvesting in this region. In order to assess plant damages, two extra treatments (totaling eight) were set, performing a control with manual harvesting with the aid of a portable coffee harvester.

The experimental design was a completely randomized block with four replications, totaling 28 plots. These plots were composed of fourteen plants spaced in $30 \mathrm{~m}$ from each other.

Coffee yields were determined by manually threshing seven plants per plot, prior to harvester passing. Stripping cloths of $6.0 \mathrm{~m} \times 2.0 \mathrm{~m}$ were placed on the ground, under plant canopy and on both sides, overlapping one to another. After that, berries were manually detached and the sampled volume was quantified individually by using a graduated container, which is used to yield calculations ( L plant $^{-1}$ ).

From the harvested amount, a $2 \mathrm{~L}$ rate was taken to determine ripeness, segregating them into green, cherry, raisin and over ripped stages. For that, one $\mathrm{kg}$ of coffee was weighted and later left to dry, remaining at an $11.5 \%$ relative humidity. Then, the sample was again weighted, processed and newly weighted. By these data, we converted the kilograms of harvested coffee to bags per hectare, using the same rate in the entire experiment.

The harvest parameters consisted of quantifying amounts of fallen, remaining and harvested coffee grains, besides calculating harvesting efficiency, using stripping cloths placed under seven plants within the plots. These cloths were fixed in the ground with $20-\mathrm{cm}$ steel beam pieces to prevent displacement during harvest.

Next harvester passage, coffee grains that have fallen on the cloths were sampled and volumes were measured (fallen coffee). After the berries have been separated, they were again placed under the foot of the trees; those berries still attached to the plants were then manually removed and measured (remaining coffee). Afterwards, we determined the amount of harvested coffee (equation 01), and with these values, we could calculate harvesting efficiency (equation 02):

$$
\begin{array}{r}
H c q=I c q-F c q-R c q \\
H e=\frac{H c q}{I c q} \cdot 100
\end{array}
$$

Wherein:

$H e=$ Harvest efficiency $(\%)$; $\left.\mathrm{ha}^{-1}\right)$;

$H c q=$ Harvested coffee quantity (coffee bags bags ha $\left.^{-1}\right)$; bags ha $^{-1}$ )

$R c q=$ Remaining coffee quantity (coffee

Damage on plants caused by vibration of harvester rods were determined by collecting and weighting all vegetal material as leaves, branches and flower buds detached and deposited on the stripping cloths after mechanical and manual harvests.

Data regarding fallen, remaining and harvested coffee, as well as harvesting efficiency and plant damages underwent variance analysis. When appropriate, means were compared by the Tukey's test at $5 \%$ probability, relating rows and columns. Both analyzes were performed through SISVAR $\AA$ statistical software (FERREIRA, 2011).

In experiment two, treatments consisted of five slopes for each block $(10,15,20,25$ and 30\%). Each block had five replicates composed by a coffee plant row. A strip experimental design with 25 plots of $200 \mathrm{~m}$ or 280 plants was used in evaluations. Then, harvest was held at an operating ground speed of $1,000 \mathrm{~m} \mathrm{~h}^{-1}$ and rotation of $800 \mathrm{rpm}$ in all treatments.

Hereupon, we started checking the harvested amount and harvesting efficiency. In this experiment efficiency calculations were carried out in a different manner, since here, conditions were distinctive from those in experiment one. Therefore, it was performed in the following manner: after harvesting each line (replication), the amount deposited on cloths was removed, measured and converted into coffee bags per hectare, emptying the grain tank after finishing each plot (harvested coffee). Based on the harvested amount, harvesting efficiency can be estimated according to equation 3 .

$$
H e 2=\frac{C T}{C Y} X 100
$$

Wherein:

$\mathrm{He} 2=$ Harvesting efficiency $(\%)$;

$C T=$ Coffee inside the harvester's tank (L);

$C Y=$ Coffee yield (L).

In addition to the total time spent by harvesting $(\mathrm{TH})$, which is measured from the beginning to the end of the operation. We also measured the effective harvest time (ETH), accounting solely the time the harvester is removing coffee cherries. Besides these, we measured the total downtime (ST), which accounts maneuver time (TM) spent to enter and leave planting rows. With the results, we could estimate the percentages for each time, discriminating effective from theoretical harvest time.

The operational times were accounted since the beginning of harvest at each line, when harvester had already been positioned for operation and, after 
finishing each line and harvester had already left planting row, timer was switched off.

Three chronometers were used for measurements. One of them recorded total harvest time (activated at the beginning of each operation), another one accounted time spent for maneuvers (activated only during maneuvers), and a third one registered downtime (comprising maneuvers and any other interruption during harvest). Thus, effective harvest time was considered as the difference between total time and downtime.

When comparing effective and theoretical times, we adopted a theoretical time of $3.156 \mathrm{~h} \mathrm{~h}^{-1}$, at a speed of $1.000 \mathrm{~m} \mathrm{~h}^{-1}$ and spacing between rows of $3.8 \mathrm{~m}$, totaling 2,631.57 $\mathrm{m}$ total path. Moreover, we assumed downtime was on average $20 \%$ theoretical time, as indicated by Silva et al. (2004).

The operating field capacity (ha $\mathrm{h}^{-1}$ ) was calculated based on average ground speed while harvesting. To this end, we divided an area of 1.0 ha by the total harvest time in each treatment.

The results of total harvest time, effective harvest time, downtime and harvesting efficiency were analyzed by ANOVA and when appropriate, compared by the Tukey's test at 5\% probability.

\section{RESULTS AND DISCUSSION}

It is notable that the two major rotation speeds showed the highest amounts of fallen berries at a ground speed of $1,000 \mathrm{~m} \mathrm{~h}^{-1}$. It might have occurred because, at the highest speed, the juxtaposed plates positioned in the center of the harvester had opened more often, and as planting row spacing was of 0.7 $\mathrm{m}$, a greater amount of coffee fell through the space between plates (Table 1).

Another interesting point is that the higher the operating speed, the greater the amount of fallen coffee (Oliveira et al., 2007), especially at high yield crops (SANTINATO et al., 2015), once the internal collecting system does not follow fruit detachment, therefore, failing to collect the volume of detached coffee.

At a rotation speed of $600 \mathrm{rpm}$, the amount of fallen berries had no increase at higher ground speeds, since such rotation level detached less grains from plants. At the ground speed of $800 \mathrm{~km} \mathrm{~h}^{-1}$, higher rotation speeds did not increase the number of fallen berries, being the most appropriate speed harvesting under this situation (Table 1).

Table 1. Percentage of coffee berries fallen due to interaction between rotation and ground speeds.

\begin{tabular}{ccc}
\hline \multirow{2}{*}{ Rotation (rpm) } & \multicolumn{2}{c}{ Ground speed $\left(\mathrm{m} \mathrm{h}^{-1}\right)$} \\
\cline { 2 - 3 } & 800 & 1.000 \\
\hline 600 & $4.77 \mathrm{aA}$ & $4.10 \mathrm{bA}$ \\
800 & $6.10 \mathrm{aB}$ & $8.75 \mathrm{aA}$ \\
1,000 & $6.10 \mathrm{aB}$ & $8.78 \mathrm{aA}$ \\
\hline VC $(\%)$ & & 41.88 \\
\hline
\end{tabular}

*Means followed by the same lowercase within the columns and capital letters within the lines do not differ from each other by the Tukey's test at $5 \%$ probability.

Both ground speeds at the highest rotation showed the smallest amounts of remaining coffee; and at the lowest rotation, the amount of remaining coffee was the lowest reached in the experiment (Table 2). Oliveira et al., (2007) and Santinato et al., (2014) had observed the same results. This fact minimizes the need for further manual harvest, which is a determining factor for harvesting operation costs. According Santinato et al., (2015 b), manual harvesting costs depend on current plant fruit load, and may represent the major part of harvesting costs.

Table 2. Percentage of remaining coffee grains due to interaction between rotation and ground speeds.

\begin{tabular}{ccc}
\hline Rotation (rpm) & \multicolumn{3}{c}{ Ground speed $\left(\mathrm{m} \mathrm{h}^{-1}\right)$} \\
\cline { 2 - 3 } & 800 & 27.000 \\
\hline 600 & $27.24 \mathrm{aA}$ & $24.74 \mathrm{aA}$ \\
800 & $26.37 \mathrm{aA}$ & $19.03 \mathrm{bA}$ \\
1,000 & $11.68 \mathrm{bB}$ & \\
\hline $\mathrm{VC}(\%)$ & & 34.91 \\
\hline
\end{tabular}

*Means followed by the same lowercase within the columns and capital letters within the lines do not differ from each other by the Tukey's test at $5 \%$ probability.

Concerning harvesting efficiency, the lowest ground speed showed no difference between 600 and $800 \mathrm{rpm}$ (Table 3). The highest rotation promoted $21.4 \%$ increase in harvesting efficiency when compared to the average of the two lower vibrations (surplus of 3.4 coffee bags $\mathrm{ha}^{-1}$ ). At higher ground speeds, there was no difference among the three vibrations assessed. Comparing both ground speeds, 
the lowest one had a harvesting efficiency $13.9 \%$ higher at $1,000 \mathrm{rpm}$.

Based on recommendations and evaluated conditions, we may infer that harvesting activities at a ground speed of $800 \mathrm{~m} \mathrm{~h}^{-1}$ and rod rotation at 1,000 rpm enhanced operational efficiency, lessened amounts of remaining coffee grains and so reducing costs.

Table 3. Harvest efficiency (\%) due to interaction between rotation and ground speeds.

\begin{tabular}{ccc}
\hline \multirow{2}{*}{ Rotation (rpm) } & \multicolumn{2}{c}{ Ground speed $\left(\mathrm{m} \mathrm{h}^{-1}\right)$} \\
\cline { 2 - 3 } & 800 & 1.000 \\
\hline 600 & $67.90 \mathrm{bA}$ & $68.67 \mathrm{aA}$ \\
800 & $67.50 \mathrm{bA}$ & $66.50 \mathrm{aA}$ \\
1,000 & $82.20 \mathrm{aA}$ & $72.19 \mathrm{aB}$ \\
\hline VC (\%) & & 10.18 \\
\hline
\end{tabular}

*Means followed by the same lowercase within the columns and capital letters within the lines do not differ from each other by the Tukey's test at $5 \%$ probability.

Overall damage plant values observed in this experiment were similar to those found in literature (SILVA et al., 2010; SILVA et al., 2013; SANTINATO et al., 2014 b). It is noteworthy mention that mechanical harvesting was less damaging compared to manual. Likewise, manual harvesting with the aid of a portable harvester after mechanized harvesting increased damages not differing from exclusively manual harvesting (Table 4). Portable detachment devices are widely employed in the southern region of Minas Gerais and in coffee plantations of Colombia (MEJÍA et al., 2013).

Increasing plant damages reduced crop yield in the following harvest (SANTINATO et al., 2014 b). Such reduced yield may be derived from injuries in internodes and, in some cases, losses of flower buds that will generate further fruit loads (DAMATTA et al., 2007). After going through a leaf shedding, coffee plants redirect metabolites to vegetative recovery processes instead of fruit production, reducing productivity (MATIELLO et al., 2010).

As already noted in the literature, high rotation speeds in mechanized harvesting increase the amount of damages to plants of coffee (Oliveira et al., 2007). Nonetheless, it was observed only for the highest ground speed and the lowest rotation. At lower ground speeds, working at 600 to $1,000 \mathrm{rpm}$, the same amount of plant damage was found, that is, settings of $800 \mathrm{~m} \mathrm{~h}^{-1}$ ground speed at $1,000 \mathrm{rpm}$ can also be recommended (Table 4).

Table 4. Amount of plant damaged $\left(\mathrm{kg} \mathrm{plant}^{-1}\right)$ due to interaction between rotation and ground speeds.

\begin{tabular}{ccc}
\hline Rotation $(\mathrm{rpm})$ & \multicolumn{2}{c}{ Ground speed $\left(\mathrm{m} \mathrm{h}^{-1}\right)$} \\
\cline { 2 - 3 } & $1.99 \mathrm{bA}$ & 1.000 \\
\hline 600 & $2.14 \mathrm{bA}$ & $1.51 \mathrm{cB}$ \\
800 & $2.05 \mathrm{bA}$ & $2.01 \mathrm{bA}$ \\
\hline 1,000 & \multicolumn{2}{c}{} \\
\hline Manual harvesting & $2.57 \mathrm{a}$ \\
\hline Semi-mechanized harvesting using a portable & $2.44 \mathrm{a}$ \\
\hline VCtachment device $(\%)$ & 13.01 \\
\hline
\end{tabular}

*Means followed by the same lowercase within the columns and capital letters within the lines do not differ from each other by the Tukey's test at $5 \%$ probability.

We observed operational field capacities of $0.24,0.23,0.24,0.18$ and $0.18 \mathrm{ha} \mathrm{h}^{-1}$, for terrain slopes of 10, 15, 20, 25 and $30 \%$, respectively. Thus, the largest difference between treatments was of 0.06 ha $\mathrm{h}-1 \mathrm{~h}$; as a result, at high slopes (25 and 30\%), 203 less trees are harvested per hour whether compared to a $10 \%$ slope.

For instance, on a working day of 8 hours, harvestings at high slopes will harvest 1,621 plants less, that is, 0.5 ha less than at $10 \%$ slope. In a general view, within sixty days, which is the time required for mechanized harvesting fulfilling the task, in some farms, the total harvested area would reach 30 ha less, that way there would be a great impact on machinery design.

Interestingly, the total harvesting time (Table 5) was higher in slopes of 25 and $30 \%$, without showing any significant difference among 10, 15 and $20 \%$. This longer time can be explained by the fact that at higher slopes, the harvester cannot reach an adequate ground speed $\left(1,000 \mathrm{~m} \mathrm{~h}^{-1}\right)$ throughout the path. On average, harvesting the two highest slopes demanded $21.6 \%$ more time than the lowest slope.

There are differences between effective and theoretical harvest times that vary from 0.94 to 1.19 ha $\mathrm{h}^{-1}$ at the lowest slope (29 and $37 \%$ greater), and 
between 2.15 and $2.22 \mathrm{ha} \mathrm{h}^{-1}$ at the two highest slopes (68.0 to $70.48 \%$ increase) (Table 5).

When evaluated globally, it was noted that effective times ranged between 70.82 and $89.38 \%$ total operation time, which clearly means that downtimes are responsible for 10.66 to $29.18 \%$ total time (Table 5).

Therefore, land steepness imposes operational limitations for mechanized harvesting, demanding longer times due to maneuvers and adjustments of the cylinders that regulate height at the beginning of process, i.e. before starting operation at each planting row, among other interruptions.

As lately adopted, in most dense stands, such as $3.6 \mathrm{~m}$ between rows and $1.0 \mathrm{~m}$ between plants, and not designed for mechanized harvesting, many more maneuvers were required interfering more with the effective harvesting time.

Table 6 displays the downtimes that varied from 0.51 to $1.54 \mathrm{~h} \mathrm{ha}^{-1}$, increasing with slope. Downtime was significantly amended by maneuvers up to $25 \%$ slope. The operating time ranged according to the size of the stands and roads, planting spacing and land ripples. In the highest declivity, the major factor in stopping time was other shutdown occasions, since harvester had to stop operating for height settings along the route.

Table 5. Total real time for mechanical harvesting of coffee plants, difference between real and theoretical time, effective harvest time and downtime at five different terrain slopes.

\begin{tabular}{|c|c|c|c|c|c|}
\hline \multirow{3}{*}{ Slopes $(\%)$} & \multicolumn{5}{|c|}{ Time } \\
\hline & Real time & Differen & -Theoretical) & $\begin{array}{c}\text { Effective } \\
\text { Harvest }\end{array}$ & Downtime \\
\hline & \multicolumn{2}{|c|}{------------(h ha $\left.{ }^{-1}\right)--------$} & \multicolumn{3}{|c|}{ 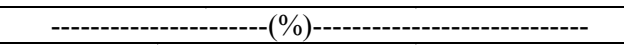 } \\
\hline 10 & $4.13 \mathrm{a}$ & $0.97 \mathrm{a}$ & $30.81 \mathrm{a}$ & $82.33 \mathrm{a}$ & $17.77 \mathrm{a}$ \\
\hline 15 & $4.34 \mathrm{a}$ & $1.19 \mathrm{a}$ & $37.65 \mathrm{a}$ & $89.38 \mathrm{a}$ & $10.66 \mathrm{a}$ \\
\hline 20 & $4.10 \mathrm{a}$ & $0.94 \mathrm{a}$ & $29.79 \mathrm{a}$ & $87.50 \mathrm{a}$ & $12.48 \mathrm{a}$ \\
\hline 25 & $5.38 \mathrm{~b}$ & $2.22 \mathrm{~b}$ & $70.48 \mathrm{~b}$ & $80.73 \mathrm{a}$ & $19.28 \mathrm{a}$ \\
\hline 30 & $5.31 \mathrm{~b}$ & $2.15 \mathrm{~b}$ & $68.10 \mathrm{~b}$ & $70.82 \mathrm{~b}$ & $29.18 \mathrm{~b}$ \\
\hline
\end{tabular}

*Means followed by the same lowercase within the columns and capital letters within the lines do not differ from each other by the Tukey's test at $5 \%$ probability.

Table 6. Downtimes during mechanized harvesting of coffee plants and their respective composition at five different terrain slopes.

\begin{tabular}{|c|c|c|c|}
\hline \multirow{2}{*}{ Slope $(\%)$} & Downtime & Maneuvering time & Other shutdowns \\
\hline & $\left(\mathrm{h} \mathrm{ha}^{-1}\right)$ & \multicolumn{2}{|c|}{--------------------------"\%o------------------------- } \\
\hline 10 & $0.73 \mathrm{a}$ & 69.89 & 30.11 \\
\hline 15 & $0.46 \mathrm{a}$ & 73.70 & 26.30 \\
\hline 20 & $0.51 \mathrm{a}$ & 61.98 & 38.02 \\
\hline 25 & $1.04 \mathrm{a}$ & 73.24 & 26.76 \\
\hline 30 & $1.54 \mathrm{~b}$ & 40.92 & 59.08 \\
\hline
\end{tabular}

*Means followed by the same lowercase within the columns and capital letters within the lines do not differ from each other by the Tukey's test at $5 \%$ probability.

Regarding the different slopes, there was no difference in harvesting efficiency among treatments. The harvester had a satisfactory efficiency at all evaluated slopes, ranging from 53.56 to $66.08 \%$, which is a range considered appropriate for this type of harvest (SILVA et al., 2013; SANTINATO et al., 2014 a).

Table 7. Harvesting efficiency at five different terrain slopes.

\begin{tabular}{cc}
\hline \multirow{2}{*}{ Slope $(\%)$} & Harvesting efficiency \\
\cline { 2 - 3 } & $(\%)$ \\
10 & $63.38 \mathrm{a}$ \\
20 & $66.08 \mathrm{a}$ \\
25 & $53.56 \mathrm{a}$ \\
30 & $58.57 \mathrm{a}$ \\
\hline
\end{tabular}

*Means followed by the same lowercase within the columns and capital letters within the lines do not differ from each other by the Tukey's test at $5 \%$ probability. 


\section{CONCLUSIONS}

In typical plantations of the southern region of Minas Gerais, lower ground speeds are most efficient $\left(800 \mathrm{~m} \mathrm{~h}^{-1}\right)$ as well as higher rotation levels (1,000 rpm).

At slopes above 20\%, mechanized harvesting demands $21.6 \%$ more time to be accomplished than in lower slopes.

Effective times for mechanized coffee harvesting vary from 70.82 to $89.38 \%$, depending on the terrain slope.

The downtime in mechanized harvesting corresponds from 10.66 to $29.18 \%$ total harvest time, varying with the number of maneuvers.

\section{REFERENCES}

CÁRDENAS, E. L. M. et al. Development of a new striker for a portable coffee harvesting tool. Revista da Faculdade Nacional de Agronomia de Medellín, Medellín, v. 66, n. 2, p. 7071-7083, 2013.

CÁRDENAS, E. L. M.; TASCÓN, C. E. O.; MEJÍA, F. A. A portable device to assist in the harvest of coffee in Colombia. Revista da Faculdade Nacional de Agronomia de Medellín, Medellín, v. 68, n. 1, p. 7471-7479, 2015.

CONAB - COMPANHIA NACIONAL DE ABASTECIMENTO. Indicadores agropecuários. Disponível em: http://www.conab.gov.br. Acesso em: 10 mar. 2014.

Da MATTA, F. M. et al. Ecophysiology of coffee growth and production. Brazilian Journal Plant Physiology, Campos dos Goytacazes, v. 19, n. 4, p. 485-510, 2007.

FERREIRA, D. F. Sisvar: a computer statistical analysis system. Ciência e Agrotecnologia, Lavras, v. 35, n. 6, p. 1039-1042, 2011.

KÖEPPEN, W. Climatologia: con um estúdio de los climas de la Tierra. México: Fondo de Cultura Economica, 1948. 478 p.

LANNA, G. B. M.; REIS, P. R. Influência da mecanização da colheita na viabilidade econômicofinanceira da cafeicultura no sul de Minas Gerais. Coffee Science, Lavras, v. 7, n. 2, p. 110-121, 2012.

MATIELLO, J. B. et al. Cultura de café no Brasil: Novo Manual de Recomendações. Rio de Janeiro e Varginha: MAPA/PROCAFÉ, 2010. 542 p.

MEJÍA, F. A.; TASCÓN, C. E. O.; URIBE, J. R. S. Evaluation of mechanical beaters in coffee harvesting. Revista da Faculdade Nacional de Agronomia de Medellín, Medellín, v. 66, n. 1, p. 6919-6928, 2013.

OLIVEIRA, E. et al. Influência da vibração das hastes e da velocidade de deslocamento da colhedora no processo de colheita mecanizada do café. Engenharia Agrícola, Jaboticabal, v. 27, n. 3, p. 714-721, 2007a.

OLIVEIRA, E. et al. Custos operacionais da colheita mecanizada do cafeeiro. Pesquisa Agropecuária Brasileira, Brasília, v. 42, n. 6, p. 827-831, 2007 b.

SANTINATO, F. et al. Número de operações mecanizadas na colheita do café. Ciência Rural, Santa Maria, v. 45, n. 10, p. 1809-1814, 2015a.

SANTINATO, F. et al. Análise econômica da colheita mecanizada do café utilizando repetidas operações da colhedora. Coffee Science, Lavras, v. 10, n. 4, p. 402-4011, 2015 b.

SANTINATO, F. et al. Análise quali-quantitativa da operação de colheita mecanizada de café em duas safras. Coffee Science, Lavras, v. 9, n.4, p. 495-505, 2014a.

SANTINATO, F. et al. Efeitos fisiológicos na cultura do café decorrentes da utilização de uma a seis passadas da colhedora. In: CONGRESSO BRASILEIRO DE PESQUISAS CAFEEIRAS,39., 2014, Serra Negra. Anais... Serra Negra: MAPA/ PROCAFÉ, 2014b. p. 204-207.

SILVA, F. C. et al. Desempenho operacional da colheita mecanizada e seletiva do café em função da força de desprendimento dos frutos. Coffee Science, Lavras, v. 8, n. 1, p. 53-60, 2013.

SILVA, F. M. et al. Efeitos da colheita manual na bienalidade do cafeeiro em Ijací, Minas Gerais. Ciência e Agro tecnologia, Lavras, v. 34, n. 3, p. 625-632, 2010.

SILVA, F. M. et al. Potencialidade de mecanização da região sul e sudoeste de minas gerais, visando a lavoura cafeeira. In SIMPÓSIO DE PESQUISA DOS CAFÉS DO BRASIL, 6., 2009, Vitória. Anais... Vitória: EMBRAPA, 2009. p. 1-6. 